\title{
Recessive COL4A2 Mutation Leads to Intellectual Disability, Epilepsy, and Spastic Cerebral Palsy
}

Neurol Genet 2021;7:e611. doi:10.1212/NXG.0000000000000611

In the Clinical/Scientific Notes article "Recessive COL4A2 Mutation Leads to Intellectual Disability, Epilepsy, and Spastic Cerebral Palsy" by Bakhtiari et al., ${ }^{1}$ the sixth author's name should be listed as "Saghar Ghasemi Firouzabadi." The editorial staff regret the error. Additionally, Dr. Hossein Darvish's affiliation should have been listed as "Neuroscience Research Center, Faculty of Medicine, Golestan University of Medical Sciences, Gorgan, Iran.” The authors regret the error.

\section{Reference}

1. Bakhtiari S, Tafakhori A, Jin SC, et al. Recessive COL4A2 mutation leads to intellectual disability, epilepsy, and spastic cerebral palsy. Neurol Genet 2021;7(3):e583. doi: 10.1212/NXG.0000000000000583. 


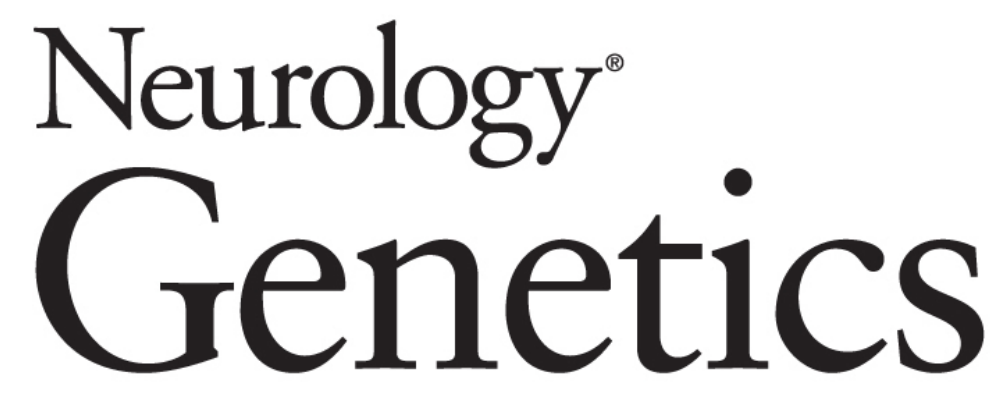

\section{Recessive COL4A2 Mutation Leads to Intellectual Disability, Epilepsy, and Spastic Cerebral Palsy \\ Neurol Genet 2021;7; \\ DOI 10.1212/NXG.0000000000000611}

This information is current as of July 1, 2021

\section{Updated Information \& Services}

References

Permissions \& Licensing

Reprints including high resolution figures, can be found at: http://ng.neurology.org/content/7/4/e611.full.html

This article cites 1 articles, 1 of which you can access for free at: http://ng.neurology.org/content/7/4/e611.full.html\#\#ref-list-1

Information about reproducing this article in parts (figures,tables) or in its entirety can be found online at:

http://ng.neurology.org/misc/about.xhtml\#permissions

Information about ordering reprints can be found online: http://ng.neurology.org/misc/addir.xhtml\#reprintsus

Neurol Genet is an official journal of the American Academy of Neurology. Published since April 2015, it is an open-access, online-only, continuous publication journal. Copyright @ 2021 American Academy of Neurology. All rights reserved. Online ISSN: 2376-7839.

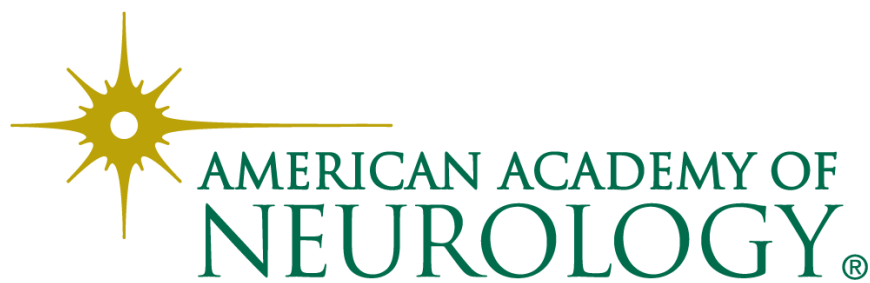

